\title{
ANALISIS HUKUM ISLAM TERHADAP PRAKTIK JUAL BELI HASIL PERTANIAN PADI SISTEM TEBASAN DI DUSUN KELIR DESA BUNDER KECAMATAN KABAT KABUPATEN BANYUWANGI
}

\author{
Abdul Kholiq Syafa'at ${ }^{1}$, Rohmatulloh ${ }^{2}$ \\ UIN Sunan Ampel Surabayal, IAI Darussalam Blokagung Banyuwangi ${ }^{2}$ \\ Email: abdulkholiqsyafaat@gmail.com ${ }^{1}$, kangrohmat32@gmail.com²
}

\begin{abstract}
The purpose of this study is: To find out the practice of buying and selling agricultural products for the rice slash system in Kelir Village, Bunder Village, Kabat District, Banyuwangi Regency. As well as to find out the review of Islamic Law on the practice of buying and selling agricultural products for rice, the cutting system. This type of research is qualitative research. Data analysis techniques used in this study are interactive models. The result of this research is the practice of buying and selling rice as follows: first the seller will offer rice to the buyer, then the buyer will come to survey and make some estimates regarding the price of rice, after being surveyed will be bargained to reach an agreement with the farmer, after that the slaughterer give a down payment (panjer) as a sign and the balance is paid when the rice is harvested. So from the results of the research that the researchers did, it can be concluded that the provisions of Islamic law on the practice of buying and selling with the slash system in Kelir Hamlet, Bunder Village, Kabat District, Banyuwangi Regency concluded that the practice of buying and selling is legal because it is in accordance with the jizaf sale and fulfillment requirements the condition of buying and selling jizaf itself.
\end{abstract}

\section{Keywords: Buy and Sell, Slash System, Islamic Law}

\begin{abstract}
Abstrak
Tujuan dari penelitian ini adalah: Untuk mengetahui Praktik Jual Beli Hasil Pertanian Padi Sistem Tebasan di Dusun Kelir Desa Bunder Kecamatan Kabat Kabupaten Banyuwangi. Serta Untuk mengetahui Tinjauan Hukum Islam terhadap Praktik Jual Beli. Jenis penelitian adalah penelitian kualitatif. Tehnik analisis data yang digunakan dalam penelitian ini adalah interaktif model. Hasil dari penelitian ini adalah praktek jual beli padi sebagai berikut pertama penjual akan menawarkan padi kepada pembeli, selanjutnya pembeli akan mendatangi untuk mensurvei dan melakukan beberapa perkiraan mengenai harga padi, setelah disurvei akan dilakukan tawar menawar untuk mencapai suatu kesepakatan dengan petani, setelah itu pihak penebas memberi uang muka (panjer) sebagai tanda jadi dan sisanya dilunasi pada saat padi dipanen. Maka dari hasil penelitian yang peneliti lakukan dapat disimpulkan bahwa Ketentuan hukum Islam terhadap praktek jual beli dengan sistem tebas di Dusun Kelir Desa Bunder Kecamatan Kabat Kabupaten Banyuwangi menyimpulkan bahwa praktek jual beli yang dilakukan sah karena sudah sesuai dengan syarat jual beli jizaf dan telah memenuhi rukun dan syarat dari jual beli jizaf itu sendiri.
\end{abstract}

Kata Kunci: Jual Beli, Sistem Tebas, Hukum Islam 


\section{A. Pendahuluan}

Manusia sebagai makhluk sosial tidak bisa hidup sendiri, artinya manusia membutuhkan interaksi satu sama lain untuk memenuhi segala kebutuhannya, salah satu bentuk interaksi yang dimaksud yaitu dibidang muamalah. Muamalah merupakan bagian dari hukum islam yang mengatur hubungan antara seseorang dengan orang lain, muamalah menyangkut permasalahan hak dan harta yang muncul dari transaksi antara seseorang dengan orang lain atau antara seseorang dengan badan hukum atau antara badan hukum yang satu dengan badan hukum yang lain (Abdullah dan Saebani. 2014:108).

Fiqih muamalah adalah pengetahuan tentang hukum-hukum syariat yang praktis, yang diambil dari dalil-dalil yang terperinci yang berkaitan dengan segala perbuatan manusia yang semua hukum asalnya boleh. Salah satunya adalah yang menjelaskan tata cara perpindahan hak milik seseorang kepada orang lain, misalnya melalui jual beli atau $a l-b a{ }^{\prime} i$. Dalam jual beli terdapat pertukaran benda yang satu dengan benda lain yang menjadi penggantinya. Akibat hukum dari jual beli adalah terjadinya perpindahan hak milik seseorang dengan orang lain atau dari penjual kepada pembeli (Abdullah dan Saebani. 2014:108)

Jual beli sebagai sarana tolong-menolong sesama manusia, dalam islam Jual beli mempunyai dasar hukum dari Al-Qur'an dan Hadis diantaranya. Ayat Al-Qur'an yang menerangkan tentang jual beli antara lain surat Al-Baqarah ayat

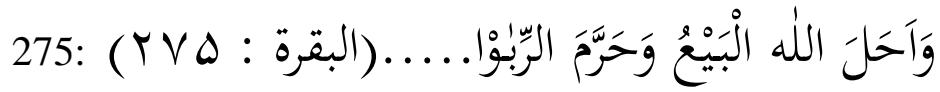

Artinya: “... Padahal Allah telah menghalalkan jual beli dan mengharamkan riba..."

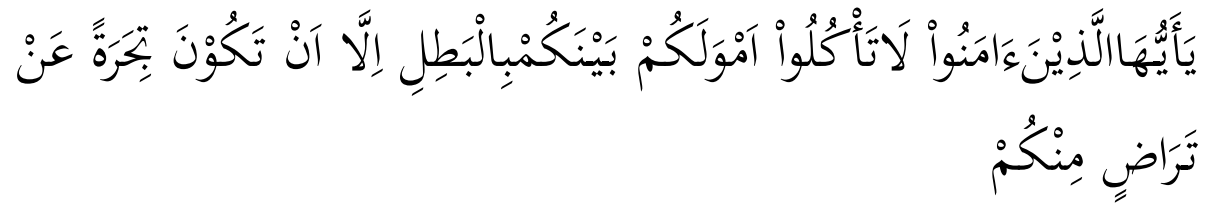

Wahai orang yang beriman, janganlah kamu memakan harta diantara kalian dengan jalan yang bathil, kecuali dengan jalan perniagaan atas dasar saling rela diantara kalian (QS. Annisa': 29).

Hadits nabi Muhammad SAW menyatakan sebagai berikut:

$$
\text { انَّاَ الْبَيْعُ عَنْ تَرَاضِ " (رواه ابن ماجهه) }
$$


"Sesungguhnya jual beli itu hanya sah jika suka sama suka." (HR Ibnu Majjah)

Rumusan masalah alam penelitian ini: 1) Bagaimanakah Praktik Jual Beli Hasil Pertanian Padi Sistem Tebasan Di Dusun Kelir Desa Bunder Kecamatan Kabat Kabupaten Banyuwangi?. 2) Bagaimanakah Analisis Hukum Islam Terhadap Praktik Jual Beli Hasil Pertanian Padi Sistem Tebasan Di Dusun Kelir Desa Bunder Kecamatan Kabat Kabupaten Banyuwangi?

\section{B. Landasan Teori}

1. Pengertian Jual Beli

Jual beli menurut kamus bahasa adalah mempertukarkan sesuatau dengan sesuatu yang lain. Sedangkan jual beli menurut syara' adalah mempermilikkan suatu harta (pada orang lain) dengan cara tukar menukar sesuau dengan mendapat ijin syara', atau mempermilikkan manfaat selamanya yang diperbolehkan syara' dengan pembayaran harga yang sebangsa harta (Fathul Qarib:30)

Kata-kata "tukar menukar sesuatu" mengecualikan akad Qardu (hutang). Dan kata-kata "dapat izin syara"" mengecualikan riba, dan kata-kata "harga" mengecualikan "upah" dalam akad sewa menyewa, karena upah dalam akad sewa-menyewa tidak dapat disebut dengan nama "harga". (fathul qarib:30)

2. Jual Beli Tebasan (Jizaf)

a. Pengertian Jual Beli Tebasan(Jizaf)

Al-jizaf ialah transaksi jual beli dengan sistem prediksi atau perkiraan. Artinya jual beli jenis komuditi yang cara atau metode mengetahui kadarnya pada dasarnya menggunakan ukuran (dzira'), timbangan (wazn), atau takaran (kail), namun dicukupkan dengan menggunakan metode takhmin (prediksi) setelah menyaksikan dengan cermat (Alhasiyyah Al-Bujairomi Ala Al-Minhaj, Juz 2:194)

b. Landasan Hukum jual Beli Tebasan atau jizaf Hadist yang diriwayatkan oleh Bukhori Muslim: 


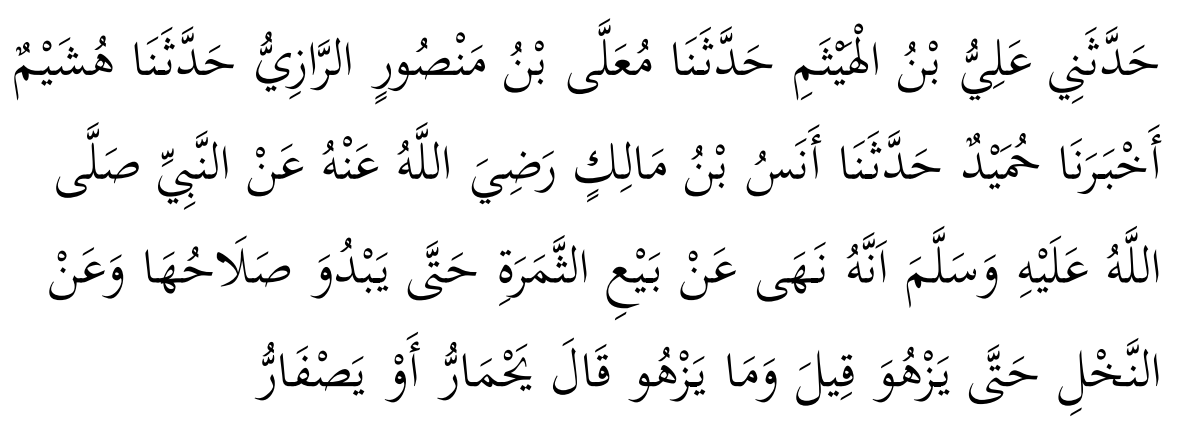

Artinya: Telah menceritakan kepadaku 'Ali bin Al Haitsam telah menceritakan kepada kami Mu'allaa bin Manshur Ar-Raziy telah menceritakan kepada kami Husyaim telah mengabarkan kepada kami Humaid telah menceritakan kepada kami Anas bin Malik radliallahu 'anhu dari Nabi shallallahu 'alaihi wasallam bahwa Beliau melarang menjual buah-buahan hingga jelas kebaikan dan (melarang pula menjual) kurma hinga sempurna. Ada yang bertanya; "Apa tanda sempurnanya?" Beliau menjawab: "Ia menjadi merah atau kuning".

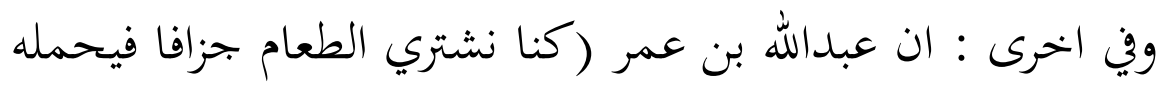

الم اهله

Artinya: Dalam riwayat yang lain sesungguhnya Abdullah bin umar membeli makanan dengan akad jizaf. Kemudian beliau membawanya kepada keluarganya (Hr. Abdullah Bin Umar)

Kesimpulan dari kedua hadits diatas bahwasanya jual beli jizaf itu diperbolehkan.

c. Cara Yang Digunakan Dalam Jual Beli Tebasan

Dalam praktiknya, tebasan bisanya dilakukan oleh penebas dengan cara membeli hasil pertanian atau perkebunan sebelum masa penen. Pengertian membeli dalam hal ini bisa diartikan dua hal, yaitu:

1) Penebas benar-benar melakukan transaksi jual-beli dengan petani pada saat biji tanaman atau buah dari pohon sudah tampak tetapi belum layak panen. Setelah transaksi, tengkulak tidak langsung memanen biji atau buah tersebut, melainkan menunggu hingga biji atau buah sudah layak panen. Pada saat itulah tengkulak baru mengambil bijiatau buah yang sudah dibelinya. Contoh kasus: Seorang penebas mendatangi petani pada saat tanaman padi sudah hamper siap untuk dipanen. Setelah bernegosiasi akhirnya penebas dan petani sepakat untuk mengadakan transaki jual-beli 
tanaman padi seluas sekian hektar dengan harga sekian juta rupiah. Dengan atau tanpa diucapkan dalam transaksi, kedua belah pihak telah memiliki kesepahaman bahwa padi baru diambil si tengkulak setelah layak panen. Kesepahaman ini muncul karena tradisi atau karena harga yang disepakati mengindikasikan bahwa si penebas memang bermaksud membeli gabah dan bukan batang padi.

2) Penebas membeli dengan menyerahkan sejumlah uang sebagai uang muka. Jika kelak barang jadi diambil maka uang yang diserahkan diperhitungkan sebagai bagian dari pembayaran, dan jika tidak jadi diambil, maka uang itu hangus. Uang muka dalam hal ini berfungsi sebagai pengikat bagi si petani, dalam pengertian bahwa si petani tidak boleh menjual hasil panennya kepada orang lain. Ditinjau dari sudut prinsip-prinsip muamalah dalam ekonomi Islam, transaksi tersebut di atas mengandung beberapa kemungkinan fasad karena buah yang masih di atas pohon, padi yang masih berada di tangkainya, atau tidak dapat diketahui kualitas dan kuantitasnya. Transaksi yang tidak diketahui kadarnya secara jelas dilarang dalam Islam. Namun apabila transaksi tersebut dilakukan oleh orang yang sudah ahli dalam bidangnya maka jual beli seperti itu dikategorikan ke dalam jual beli jizaf, yang tidak diketahui kadarnya secara jelas.

d. Syarat Jual Beli Tebasan atau Jizaf

Para fuqaha Malikiyah mensyaratkan 6 syarat untuk sahnya jual beli jizaf, sebagaimana hal ini juga ditemukan pada pendapat ulama madzhab lainnya (al-mausu'ah al-fiqhiyah, juz 9:73-76), syarat yang di maksud adalah sebagai berikut:

1) Obyek transaksi harus bisa dilihat dengan mata kepala ketika sedang melakukan akad atau sebelumnya. Ulama Hanafiyah, Syafiiyah dan Hanabilah sepakat akan syarat ini. Dengan adanya syarat ini, maka gharar jahalah (ketidaktahuan obyek) dapat dihilangkan.

2) Penjual dan pembeli tidak mengetahui secara jelas kadar obyek jual beli, baik dari segi takaran, timbangan ataupun hitungannya. Imam Ahmad menyatakan, jika penjual mengetahui kadar obyek transaksi, maka ia 
tidak perlu menjualnya secara Jizaf. Namun, jika ia tetap menjualnya secara jizaf dengan kondisi ia mengetahui kadar obyek transaksi, maka jual beli sah dan bersifat lazim, namun makruh tanzih.

3) Jual beli dilakukan atas sesuatu yang dibeli secara tebasan atau borongan, bukan per satuan. Akad Jizaf diperbolehkan atas sesuatu yang bisa ditakar atau ditimbang, seperti biji-bijian dan yang sejenisnya. Jual beli Jizaf tidak bisa dilakukan atas pakaian, kendaraan yang dapat dinilai per satuannya. Berbeda dengan barang yang nilainya sangat kecil per satuannya, atau memiliki bentuk yang relatif sama. Seperti telor, apel, mangga, semangka, kurma dan sejenisnya. Jika obyek transaksi bisa dihitung tanpa adanya upaya yang melelahkan dan rumit, maka tidak boleh ditransaksikan secara jizaf, dan berlaku sebaliknya.

4) Obyek transaksi bisa ditaksir oleh orang yang memiliki keahlian dalam penaksiran. Akad jizaf tidak bisa dipraktikkan atas obyek yang sulit untuk ditaksir. Madzhab Syafiiyyah sepakat atas adanya syarat ini, mereka menetapkan bahwa kadar shubroh (kumpulan makanan tanpa ada timbangan dan takarannya) harus bisa diketahui, walaupun dengan cara menaksir.

5) Obyek akad harus banyak.

6) Tanah yang digunakan sebagai tempat penimbunan obyek transaksi haruslah rata, sehingga kadar obyek transaksi bisa ditaksir. Jika tanah dalam kondisi menggunung atau landai, maka kemungkinan kadar obyek transaksi bisa berbeda (misalnya, kacang tanah). Jika ternyata tanah dalam kondisi tidak rata, maka keduanya memiliki hak khiyar.

7) Tidak diperbolehkan mengumpulkan jual beli barang yang tidak diketahui kadarnya secara jelas, dengan barang yang diketahui kadarnya secara jelas, dalam satu akad. Misalnya, jual beli kurma satu kilo, dikumpulkan dengan apel yang berada dalam satu pohon, dengan satu harga atau dua harga (Wahbah Zuhaili penerjemah Abdul Hayyie alKattani. 2007:303). 


\section{Metode Penelitian}

Jenis penelitian yang peneliti gunakan adalah penelitian kualitatif yakni prosedur penelitian yang menghasilkan data deskriptif berupa kata-kata tertulis atau lisan dari orang-orang atau pelaku yang diamati (Lexy J Moleong. 2012:4). Obyek yang sebenarnya adalah fakta tentang praktek jual beli hasil tanam padi dengan sistem tebas di Dusun Kelir Desa Bunder Kecamatan Kabat Kabupaten Banyuwangi.

\section{Hasil}

Dalam praktek jual beli Padi siap panen di Dusun Kelir terdapat dua cara penjualan yaitu dengan sistem panen sendiri dan dengan sistem tebasan.

1. Jual Beli Hasil Panen Padi Dengan Cara Panen Sendiri:

Dalam jual beli hasil panen padi dengan cara panen sendiribiasanya petani atau pemilik sawah akan memanen padi sendiri dengan menyewa jasa para buruh tani. Selanjutnya buruh tani akan melakukan semua proses yang harus dilakukan sebelum padi siap untuk dijual seperti proses pemotongan padi, pemisahan antara daun dan biji padi/gabah secara manual atau dengan cara digiling, proses pemikulan dari sawah menuju daratanproses penimbangan, dan proses penjualan kepada tengkulak gabah.

Dengan mengacu pada hal tersebut, maka sudah jelas bahwa petani mengetahui setiap proses yang dilalui serta melakukan penawaran harga sendiri dengan tengkulak sesuai dengan harga pasar yang saat itu berlaku. Dengan demikian, hasil padi dengan cara panen sendiri ini segala sesuatu sudah dipertimbangkan dan diperhitungkan secara masak dan tidak ada unsur spekulasi atau maysir dan gharar.

2. Proses Jual Beli Hasil Panen Padi Dengan Sistem Tebas Di Dusun Kelir Desa Bunder Kecamatan Kabat Kabupaten Banyuwangi.

a. Cara menghubungi penebas

Cara yang sering petani lakukan untuk menghubungi pembeli adalah pada saat biji padi sudah menguning itupun petani tidak perlu repot-repot mencari penebas karena bisanya pada saat itu penebas bisanya sudah mendatangi sawah petani dan tak jarang juga ada penebas yang langsung 
mendatangi rumah petani, sebelumnya penebas sudah melihat-lihat kualitas dari biji padi dan sudah mentaksir jumlah harga yang akan ditawarkan kepada petani sehingga penebas bisa langsung mulai melakukan tawar menawar harga padi yang hampir siap dipanen kepada petani, Seiring bertambah moderenya zaman ada juga penebas yang melakukan tawar menawar lewat telepon.

Hal ini seperti dituturkan oleh ibu Satonah pada tanggal (27 juni 2018)

Biasane kapan pari wes meh wayae panen kiro-kiro kurang sak ulan utowo stengah ulan, wong kang tukang nebas iku morok ning sawah, onok pisan penebas kang morok ning umah. Kapan penebas arepe ning umah biasane penebas iku morok solong ning sawah ndeleng kuwalitas teko pari kang arepe dituku, engko kapan moro ning umah penebas iku kari nowokaen regok. Paran maning saiki kan wes onok Hp kadang isun langsung nelpon penebas kang ezt dadi langganan.

Hal senada juga disampaikan oleh bapak Eli (27 juni 2018)

Sak liyane nowokaen liwat Hp, kadang penebas iku ndue anak buah, engko anak buah kui bagiyan ndeleng-ndeleng ning sawah dadi penebas engko kari morok ning umah ambi anak buahe kang wes ngerti rego ambi kwalitase pari kang arepe dituku.

b. Cara melaksanakan perjanjian

Menurut hasil wawancara dengan Bapak Muin dan Bu Tik pada tanggal (28 juni 2018), dalam praktek jual beli tebasan yang terjadi di Dusun Kelir ini tidak ada perjanjian secara tertulis, melainkan hanya menggunakan akad lisan yang saling percaya antara penjual dan pembeli. Disini pada saat akad berlangsung penjual ( petani) dan pembeli ( penebas) menyatakan sebuah kesepakatan yang sudah biasa dilakukan oleh masyarakat, biasanya masyarakat menggunakan bahasa Using. Misalnya penjual sebagai petani menyatakan "isun adol pari iki (saya jual padi ini)" dan penebas menjawab, "isun tuku pari iki teko riko (saya beli padi ini dari anda)". Maka dalam hal ini telah terjadi kesepakatan atau perjanjian yang bisa diterima oleh kedua belah pihak. Setelah terjadi kesepakatan dari kedua belah pihak, maka penebas memberi uang muka (panjer) untuk tanda jadi.

Biasanek kapan masalah perjanjian iku mong nganggo omongan tok, heng onok perjanjian tertulis. Soale iku yo wes dadi kebiasaane petani 
ning kenek. Engko kapan rego wes sepakat, wong kang tukang nebas biasane ngopai picis dingo panjer.

c. Cara menetapkan harga

Menurut bapak Sunar selaku penebas (wawancara pada 26 juni 2018) dalam penetapan harga padi tergantung pada kesepakatan orang yang melakukan transaksi, bisaanya penjual dan pembeli melakukan tawar menawar hingga terjadi kesepakatan yang saling menguntungkan bagi kedua belah pihak.

Dalam penetapan harga padi biasanya sebelum bernegosiasi dengan petani, penebas terlebih dahulu menanyakan harga padi kepada pengepul, setelah harga padi diketahui oleh penebas, penebas bisa langsung melakukan tawar menawar dengan petani hingga terjadi kesepakatan antara kedua belah pihak.

Carane nentokaen rego yoiku biyasane isun nganggo coro jangkahan, yoiku isun njangkai sawah kang arep hun tukudowok ambi werone. Engko kapan rego wes ketemu, buru isun padu rego ambi wongkang nandur pari.

Hal senada juga disampaikan oleh bapak Supri selaku penebas (wawancara pada 26 juni 2018)

Sak durunge isun morok ning sawah kang arep hun tuku, isun morok sulung ning umae pengepul pari engko isun ningkunu takon regone pari pas dino iku kerono regone pari iku heng mesti tetep. Kadang mundak, kadang yo mudun. Kapan regone wes ketemu, buru isun langsung moro ning sawah kang arepe hun tebas. Biyasane isun nganggo sistim jangkahan.

d. Cara menyerahkan hasil panen

Menurut bapak Sunar dan bapak Supri (wawancara pada 26 juni 2018) setelah terjadi kesepakatan antara petani dan penebas, biji padi yang masih belum waktunya dipanen itu masih tanggung jawab petani untuk merawat hingga biji padi siap dipanen. Dengan demikian kedua belah pihak masih memiliki ikatan sampai padi siap untuk dipanen, dan pelunasannya dibayar pada saat padi selesai dipanen.

Sakwise padurego sukses ambi petani, isun mbayar picis dienggo panjer. Picis panjer iku dienggo bukti kapan isun pocok tuku parine 
petani. Tapi pari iku heng langsung isun panen, soale pari iku mau dorong siap dipanen. Mulo pari iku wes dadi milik isun, tapi petani yo mageh duwek tanggungan njogo pari iku mau sampek isun manen parine kapan masalah pelunasan isun ngelunasi pas wayae panen.

e. Cara melakukan pembayaran

Seperti yang dijelaskan oleh bapak Supri selaku penebas (wawancara pada 26 juni 2018) pembayaran dalam jual beli tebasan bisaanya dilakukan dengan dua kali tahapan, tahapan yang pertama dibayar pada saat terjadi kesepakatan harga antara petani dan penebas dan pihak penebas nantinya memberi uang muka (panjer) kepada petani dan tahapan yang kedua yaitu tahap pelunasan bisaanya akan dilunasi pada saat padi dipanen, akad dalam jual beli tebasan biasanya dilakukan dengan asas saling percaya antara kedua belah pihak. Penebas menawarkan harga pembelian hasil panen padi kepada petani dengan cara menaksir harga tanaman padi saat itu, ketika nanti pada saat panen semua pembayaran akan segera dilunasi, tetapi pada saat terjadi akad dan biji padi juga belum siap dipanen, petani hanya mendapatkan pembayaran uang mukanya saja, banyaknya uang muka yang dibayarkan tergantung kesepakatan yang dilakukan antara petani dan penebas, bisaanya $25 \%$ dari harga jual.

Mbayare diangsur ping pinduk pertama pas padurego ambi petani, kapan pelunasane iku dibayar pas panen. Biyasanek picis panjer iku slawe persen teko picis total rego kesepakatan.

3. Faktor-Faktor Yang Menyebabkan Praktek Jual Beli Padi Dengan Sistem Tebasan Di Dusun Kelir Desa Bunder Kecamatan Kabat Kabupaten Banyuwangi.

Berikut beberapa faktor yang menyebabkan petani di Dusun Kelir Desa Bunder Kecamatan Kabat Kabupaten Banyuwangi masih menggemari praktek jual beli padi dengan system tebas:

a. Menurut bapak sunar selaku penebas (wawancara pada 26 juni 2018) transaksi lebih mudah yaitu hanya dengan mengukur panjang dan lebar sawah dan melihat kondisi biji padi, penebas sudah dapat melihat kualitas 
dan kuantitas dari biji padi yang masih berada di tangkainya dan penebas sudah dapat menentukan harga yang akan ditawarkan kepada petani.

Transaksine gampang yoiku isun mong njangkai sawah kang arep hun tuku ambi ndeleng kwalitas teko pari iku. Engko kapan wes ngerti dowok ambi werone sawah iku isun gari ngiro-ngiro rego kanga rep hun towokaen ning petani.

b. Menurut bapak Supri selaku penebas (wawancara pada 26 juni 2018), proses transaksinya tidak perlu berbelit-belit yaitu padi yang ditebas tidak perlu melalui proses penimbangan karena penebas langsung membeli dengan borongan, waktunya lebih efektif karena kebanyakan penebas sudah bekerjasama langsung dengan tengkulak (pengepul) jadi, setelah memanen padi penebas langsung menyetorkan hasil panen kepada trengkulak.

Carane gampang, heng usah repot-repot nimbang kerono engko isun kari nggowok ning pengepul, engko pengepul nimbangi pari hasil isun mau.

c. Untuk Memudahkan Petani Dalam Penjualan

Menurut ibu Satonah, Muin, Eli dan bu Tik (wawancara pada tanggal 27 dan 28 juni 2018) iritbiyaya dan tenaga yaitu petani tidak perlu repot-repot menyewa tenaga buruh untuk memanen padi dan petani tidak perlu repot repot membawa hasil panen padi ke trengkulak. Karena selama peneliti tinggal di Dusun Kelir peneliti menyaksikan proses pemanenan padi sangat lama, jadi apabila patani menjual dengan sistem tebas petani tinggal menerima uang bersih, dan semua proses pemanenan padi akan diurus oleh pembeli atau penebas.

Biyayane irit isun heng usah ngongkon uwong ngaret, kerono kapan isun manen dewek isun kudu nunggoni ngancani ples ngopai panganan ning wong kang ngaret ambi ndoser, iku yo durung mari isun kudu ngowok ning pengepul trus ditimbang, kapan wes ditimbang ning pengepul isun buru oleh peces. Peces iku lho yo mageh kepotong dingo mbayar tukang ngaret, ndoser, ambi kang tukang nepak. Kapan isun ngedole nganggo tebasan isun langsung nampani picis, picise tebasan iku lho y owes bersih, isun heng usah ngongkosi wong ngaret, kang ndoser ambi kang tukang nepak. 


\section{E. Pembahasan}

1. Analisis Praktik Jual Beli Hasil Pertanian Padi Sistem Tebasan Di Dusun Kelir Desa Bunder Kecamatan Kabat Kabupaten Banyuwangi

Menurut hasil wawancara dengan ibu Satonah selaku petani (wawancara pada tanggal 27 juni 2018), transaksi jual beli dengan sistem tebasan bisaanya dilakukan jika biji padi sudah hampirmenguning kira kira padi sudah berumur 3 stengah bulan, apabila padi sudah berumur 3 stengah bulan para penebas sudah melakukan survey, dan tak jarang juga ada penebas yang memiliki orang suruhan untuk melakukan survey ke sawah petani, lahan petani yang ditanami padi oleh masyarakat dusun kelir sangatlah berfareatif mulai dari seperempat hektar ada juga yang sampai satu hektar lebih. Ibu Satona menambahkan bisaanya sawah $1 \mathrm{Ha}$ itu minimal mendapat uang bersih Rp. 20.000.000,00.

Menurut bapak Sunar dan bapak Supri selaku penebas (wawancara pada tanggal 26 juni 2018), setelah melihat langsung lahan petani yang digunakan untuk menanam padi dan harganya sudah diketahui, barulah kedua belah pihak (petani dan penebas) melakukan transaksi (ijab dan qabul) dengan ketentuan harga yang telah disepakati bersama setelah itu penebas memberi uang muka (panjer) sebesar 25\% sebagai tanda jadi dan sisanya akan dilunasi pada saat panen. Pada jual beli tebasan sendiri perjanjiannya (ijab dan qabul) hanya menggunakan akad lisan dan asas kepercayaan tidak ada perjanjian secara tertulis.

Setelah kedua belah pihak sudah melakukan transaksi dan telah terjadi kesepakatan antara petani dan penebas, padi tidak bisa langsung di panen, melainkan penebas harus menunggu padi sampai menguning dan siap untuk dipanen, itupun petani bukan semata-mata sudah terlepas dari tanggung jawabnya, melainkan petani masih memiliki tanggungan untuk merawat padi sampai padi dipanen oleh penebas. Dengan demikian kedua belah pihak (petani dan penebas) masih memiliki ikatan sampai barang dipanen oleh pembeli dan uang pelunasan diterima oleh petani. 
2. Analisis Tinjauan Hukum Islam TerhadapP raktek Jual Beli Padi Dengan System Tebas Di Dusun Kelir Desa Bunder Kecamatan Kabat Kabupaten Banyuwangi

Menurut hasil wawancara dengan ibu Satonah selaku petani (wawancara pada tanggal 27 juni 2018), transaksi jual beli dengan system tebasan bisaanya dilakukan jika biji padi sudah hampir menguning kira kira padi sudah berumur tiga stengah bulan.

Menurut bapak Sunar dan bapak Supri selaku penebas (wawancara pada tanggal 26 juni 2018), setelah melihat langsung lahan petani yang digunakan untuk menanam padi dan harganya sudah diketahui, barulah kedua belah pihak (petani dan penebas) melakukan transaksi (ijab dan qabul) dengan ketentuan harga yang telah disepakati bersama setelah itu penebas memberi uang muka (panjer) sebesar 25\% sebagai tanda jadi dan sisanya akan dilunasi pada saat panen. Pada jual beli tebasan sendiri perjanjiannya (ijab dan qabul) hanya menggunakan akad lisan dan asas kepercayaan tidak ada perjanjian secara tertulis.

Setelah kedua belah pihak sudah melakukan transaksi dan telah terjadi kesepakatan antara petani dan penebas, padi tidak bisa langsung di panen, melainkan penebas harus menunggu padi sampai menguning dan siap untuk dipanen, itupun petani bukan semata-mata sudah terlepas dari tanggung jawabnya, melainkan petani masih memiliki tanggungan untuk merawat padi sampai padi dipanen oleh penebas. Dengan demikian kedua belah pihak (petani dan penebas) masih memiliki ikatan sampai barang dipanen oleh pembeli dan uang pelunasan diterima oleh petani.

Dari hasil wawncara diatas dapat disimpulkan bahwa praktek jual beli padi dengan system tebas di Dusun Kelir Desa Bunder Kecamatan Kabat Kabupaten Banyuwangi dipandang sah karena sesuai dengan hukum Islam. Menurut pendapat dan teori dibawah ini. Menurut Aizza Aly Shofa ( 2016: 10-11), dalam analisis hukum Islam terhadap transaksi jual beli padi dengan sistem tebas itu terdapat beberapa kemungkinan fasad. Yaitu:

a. Muhaqallah (menjual tanaman yang masih di ladang atau sawah).

Muhaqallah dilarang agama sebab ada persangkaan riba didalamnya. 
Dalam praktiknya, transaksi jual beli padi dengan sistem tebasan di Dusun Kelir terjadi ketika biji padi sudah terlihat dan hampir menguning tetapi masih belum layak untuk dipanen. Bisaanya transaksi jual beli dilakukan satu minggu sebelum masa panen, sehingga kecil kemungkinan terjadi gagal panen.

b. Muzabanah (menjual buah yang basah dengan buah yang kering). Jika tebasan dilakukan dengan cara barter dengan komoditas sejenis, seperti padi ditukar dengan gabah (muzabanah), maka akan terjadi riba fadl. Sedangkan jual beli padi tebasan di Dusun Kelir tidak ada yang memakai sistem barter dengan komoditas sejenis. Sesuai dengan kebisaaan masyarakat Dusun Kelir selalu melakukan jual beli padi tebasan dibayar dengan uang sehingga tidak akan terjadi riba fadl.

c. Spekulatif (tidak diketahui jumlahnya). Petani Dusun Kelir pada umumnya menjual padi yang masih berada di tangkainya dan tidak diketahui jumlahnya. Dengan demikian dalam transaksi tersebut dijual tanpa takaran.Hal ini diperbolehkan dalam transaksi jual beli padi tebasan karena telah memenuhi enam syarat diperbolehkannya jual beli tanpa ditimbang (jizaf) menurut madzhab Malikiyah yaitu:

1) Objek transaksi harus bisa dilihat dengan mata kepala ketika sedang melakukan akad atau sebelumnya.Objek yang dilakukan oleh petani yaitu biji padi.

2) Penjual dan pembeli tidak mengetahui secara jelas kadar objek jual beli, baik dari segi takaran, timbangan atau pun hitungannya. Karena masyarakat Dusun Kelir sebagian besar menekuni pekerjaan tani, dan rata-rata sawah petani lebih dari setengah hektar. Jadi memungkinkan karena itulah tidak mungkin petani menimbang padi sebelum dijual.

3) Objek transaksi bisa ditaksir oleh orang yang memiliki keahlian dalam penaksiran. Syarat ini terbukti karena penebas sudah lama menekuni pekerjaan sebagai penebas.

4) Objek akad harus banyak.

5) Tanah yg digunakan sebagai tempat penanaman obyek transaksi haruslah rata, sehingga kadar objeknya transaksi bisa ditaksir. Jika 
ternyata tanah dalam kondisi tidak rata, maka keduanya memiliki hak khiyar

6) Tidak diperbolehkan mengumpulkan jual beli barang yang tidak diketahui kadarnya secara jelas, dengan barang yang diketahui kadarnya. Misalnya jual beli kurma satu kilo dikumpulkan dengan apel yang berada dalam satu pohon, dengan satu harga atau dua harga.

d. Shofqotain fi shofqotin wāhid dan bai' bi syartin jarā naf'an. Jual beli tebasan padi di Dusun Kelir yang sudah dibeli tetapi masih dibiarkan, dan karenanya masih memanfaatkan tanah petani, maka memungkinkan terjadinya satu transaksi tetapi mengandung dua maksud transaksi (shofqotain fi shofqotin wāhid) atau terjadi jual beli dengan persyaratan yang menguntungkan pihak penebas, yaitu keuntungan memanfaatkan tanah bahkan perawatan dari pihak penjual (bai' bisyartin jarā naf'an). Menurut An-Nawawi jika dalam hal penjualan dilakukan dengan tanpa syarat, maka penjual berkewajiban merawat hingga saatnya panen. Dan jika terjadi gagal penen karena alam maka menurut qoul jadid Syafi'I dan Abu Hanifah resiko ditanggung pembeli. Sebab padi sudah menjadi milik pembeli ketika rusak.

\section{F. Kesimpulan}

Dari hasil pembahasan penelitian, maka idapat menyimpulkan beberapa hal antara lain:

1. Praktek jual beli padi dengan cara tebasan di Dusun Kelir Desa Bunder Kecamatan Kabat Kabupaten Banyuwangi dilakukan dengan beberapa tahap di antaranya: pertama penjual akan menawarkan padi yang akan mereka jual kepada pembeli. Selanjutnya pembeli akan mendatangi atau mensurvei padi milik petani yang akan dijual dan melakukan beberapa perkiraan mengenai harga padi yang hampir siap panen dan melihat kualitas dari biji padi yang akan dibeli. Setelah disurvei akan dilakukan tawar menawar harga dengan penjual/ petani, kemudian jika keduanya sudah sepakat dengan harganya maka dilakukan perjanjian terhadap jual beli tersebut secara lisan dan menggunakan bahasa sehari-hari atau dengan menggunakan bahasa Using, 
setelah itu pihak penebas memberi uang muka (panjer) sebagai tanda jadi dan sisanya dilunasi pada saat padi dipanen. Jual beli padi dengan sistem tebasan sudah menjadi kebisaaan yang sering dilakukan oleh masyarakat Dusun Kelir dengan maksud untuk mempermudah petani dalam proses penjualan padi yang siap panen, dan dengan harapan petani dapat mendapat uang secara cepat. karena jika petani menggunakan cara panen sendiri, akan menghabiskan banyak waktu dan biaya untuk keperluan panen dan pengolahannya.

2. Analisis hukum Islam terhadap praktek jual beli di Dusun Kelir Desa Bunder Kecamatan Kabat Kabupaten Banyuwangi penulis menyimpulkan bahwa praktek jual beli yang dilakukan sah karena sudah sesuai dengan syarat jual beli jizaf yaitu:

a. Obyek transaksi bisa dilihat dengan mata kepala ketika sedang melakukan akad atau sebelumnya, sehingga gharar jahalah atau ketidakjelasan dari objek dapat dihindari, objek pada transaksi jual beli tebas yaitu Biji padi yang hampir siap untuk dipanen.

b. Penjual dan pembeli tidak mengetahui secara jelas kadar obyek jual beli, baik dari segi takaran, timbangan ataupun hitungannya. Karena sawah petani dusun kelir lebih dari stengah hektar, jadi petani tidak mengetahui jumlah takaran, hitungan dari padi yang dimiliki petani.

c. Pihak pembeli atau penebas merupakan orang yang sudah ahli dalam bidang penaksiran tersebut.

d. Jual beli dilakukan atas sesuatu yang dibeli secara borongan, bukan per satuan. Akad jizaf diperbolehkan atas sesuatu yang bisa ditakar atau ditimbang, seperti biji-bijian dan yang sejenisnya. Objek dalam penelitian yang diperjual belikan adalah biji padi yang hampir siap dipanen dan kadar jumlahnya belum diketahui oleh petani maupun penebas maka dari itu dalam syarat ini sudah terpenuhi.

e. Obyek jual belinya yaitu padi yang hampir siap dipanen. yang sebelumnya diperkirakan ada unsur maysir dan gharar dihapuskan oleh bukti bahwapihak yang menaksir merupakan orang yang sudah kompeten atau 
ahli dalam bidangnya. Hal itu sesuai dengan salah satu syarat dalam jual beli jizaf.

f. Tanah yang digunakan sebagai tempat menanam obyek transaksi merupakan tanah yang rata dan memungkinkan untuk ditaksir.

g. Jual beli tebasan yang sedang berlangsung di Dusun Kelir tidak dicampurkan dengan sesuatu yang sudah jelas takarannya.

Dari analisis di atas penulis menyimpulkan bahwa praktek jual beli padi dengan system tebasan di Dusun Kelir Desa Bunder Kecamatan Kabat Kabupaten Banyuwangi menurut Hukum Islam diperbolehkan, karena sudah memenuhi rukun dan syarat jual beli jizaf.

\section{Daftar Pustaka}

A Partanto Pius Dan M. Dahlan Al Barry. 2001. Kamus Ilmiah Popular. Surabaya: Arkola

Abdullah,Hoedi Dan Beni Ahmad Saebani. 2014.metode penelitian ekonomi islam muamalah. Bandung: pustaka setia

Aizza Alya Shofa. 2016. Tinjauan Hukum Islam Terhadap Praktik Jual Beli Padi Dengan Sistem Tebas Di Desa Mlaten Kabupaten Demak. Surakarta: Prodi HES FAI UMS Universitas Muhammadiyah Surakarta.

Akbar, Andi Ali. 2014. Prinsip Prinsip Dasar Transaksi Syariah. Blokagung

Al-Jaziri, Abdurrohman. 2003. Alfiqhu Alalmadzahib Al-Arba'ah

Anwar, Syamsul. 2007. Hukum Perjanjian Syariah: Studi tentang Teori Akad dalam Fiqh Muamalah. Jakarta: Rajawali Pers

Basyir, Ahmad Azhar. 2000. Asas-Asas Hukum Muamalat. Yogyakarta: UII Press

Bungin, Burhan. 2013. Metode Penelitian Sosial dan Ekonomi. Jakarta: Kencana

Hardiansyah, Haris. 2010. Metodologi Penelitian Kualitatif untuk Ilmu-ilmu Sosial. Jakarta: Salemba Humanika

Hasan, Abul, Ali bin Muhammad bin Habib Al-Mawardi Al-Bashri (Imam Mawardi ). 1994. al hawi al-kabir.

https://mazinov.wordpress.com/2012/11/01/jual-beli-tebasan-danpermasalahannya/ diakses pada 12 Mei 2018 pukul 22.27

Ika Nur Yuliyanti. 2016. Tinjauan Hukum Islam Terhadap Jual Beli Buah Jeruk Dengan Sistem Borongan Di Pasar Johar Semarang. Semarang: Universitas Islam Negeri WalisongoSemarang.

Ismail, Nawari. 2015. Metodologi Penelitian untuk Studi Islam. Yogyakarta: Samudra Biru

Juju Jumena, A. Otong Busthomi dan Husnul Khotimah. 2017. Jual Beli Borongan Bawang Merah Di Desa Grinting Menurut Tinjauan Hukum Islam. Cirebon: Institut Agama Islam Negeri Syekh Nurjati Cirebon.

Kalaf, Abdul Wahab, Ilmu Ushul Fiqih, penerjemah: Moh. Zuhri dan Ahmad. 2003. fathul Qarib. Jakarta: Pustaka Amam.

Kementrian, Wakaf dan Urusan Agama Kuwait. 1883. al-maushu'ah al-fiqhiyyah. 
Miles, Matthew B. dan A Michael Huberman. 1992. Analisis data kualitatif. Jakarta: Universitas Indonesia (UI-Press)

Mohammad Daud Ali. 1996.Hukum Islam: Pengantar Ilmu Hukum dan Tata Hukum Islam di Indonesia. Jakarta: PT Raja Grafindo persada.

Muhammad bin Abul Abbas, Ahmad bin Hamzah Syihabuddin Ar-Romli. 2003. Hujairomi Ala Al-Minhaj.

Muhammad bin Qasim Al-Ghazzi. 1343. Fathul Qarib.

Nawawi Imam. 1994. Alhasiyyah Al-Bujairomi Ala Al-Minhaj.

Profil Desa Bunder Kecamatan Kabat Kabupaten Banyuwangi Tahun 2017.

Rasjidi, H.M. 1980.Kesatuan dan Keragaman dalam Islam. Jakarta: Pustaka Jaya.

Sulaiman, Bin Umar bin Mansur Al Ujaili Al Azhari Al Azhari Al Jamal (Syekh Sulaiman Al Jamal) Hasiyah Jamal,

Syaikh, Muwafiquddin Ibnu Qudamah. 1997. Al-Mughni Li-Ibniqudamah.

Syamsuddin, Muhammad bin Ahmad Al-Khotib Asy-Syarbini. 1997. Mughni AlMuhtaj.

Syekh Dr. Musthofa Bugho-Syekh Dr. Musthofa Al-Khin-Syekh Ali AsySyurbaji. 1992. Fiqih Manhaji.

Syekh Sulaiman Bin Muhammad bin Umar Al-Bujairomi. 1996. Bujairomi Alal Khotib.

Taqiyyuddin, Abu Bakar Muhammad al-Hushni. 2001. Kifayatul Akhyar.

Zuhaili,Wahbah penerjemah Abdul Hayyie al-kattani. 2007. Fiqih Islam Wa Adilatuhu. Jjilid V. Jakarta: Gema Insani. 